\title{
What Drives Mobile Banking in the Digital Age? An Empirical Examination among Consumers Young
}

\author{
Rudi Purwono a, Andhy Setyawan b, Tuwanku Aria Auliandri a*, a'Lecturer \\ in Faculty of Economics and Business, Universitas Airlangga, ${ }^{\mathbf{b}}$ Lecturer in \\ Faculty of Business and Economics, Universitas Surabaya, \\ *Corresponding Author Email: aria@feb.unair.ac.id
}

This study aims to examine the factors that encourage young consumers who intend to adopt mobile banking (m-banking) facilities in the current digital era. The empirical testing of the intention of $m$-banking adoption is based on the perspective of users who are included in the criteria of young consumers in developing countries. Young consumers in developing countries are potential markets for m-banking services in the digital era that demand the effectiveness and efficiency of banking transactions. These young consumers tend to have high mobility and are more aware of the development of m-banking technology to fulfil their needs and wants using easy, fast, and practical banking transactions. By using a purposive sampling technique, as many as 290 young consumers (18-30 years old) of $\mathrm{m}$-banking in Indonesia were chosen as respondents of this study. The data is analysed using the structural equation modeling (SEM) technique. The results showed that all factors that were thought to have a positive effect on the intention to use m-banking among young consumers supported the empirical data. The antecedent factors tested included attitude, perceived usefulness, service quality, system quality, and trust. Internal factors of m-banking users, namely attitude, perceived usefulness, and trust have a greater influence on the intention to use m-banking than external factors. The external factors are in the form of supports provided by banks to m-banking users, namely service quality and system quality.

Key words: M-Banking, Intention to Use, Young Consumer, Digital Age, Developing Country 


\section{Introduction}

The rapid development of information and communication technology (ICT) in the past decade has had a significant impact on business and industrial activities, including the financial and banking sectors. The presence of mobile banking (m-banking) is one of the mobile technology revolutions that allows users to access and conduct mobile banking transactions via smartphones so that transactions involving banks can be done anywhere, fast, easily and practically (Baabdullah et al., 2019, Zhang et al., 2018, Alalwan et al., 2017). Shareef et al. (2018) argue that m-banking is an internet banking development that provides convenience to consumers to obtain financial services from banks through mobile devices such as smartphones. M-banking can be used in various activities related to banking transactions (such as e-commerce, payment and transfer) through smartphones in the form of short message service (SMS) banking, direct call, mobile internet, and other mobile applications.

The presence of m-banking in the digital era is certainly a breakthrough that provides many benefits to consumers, especially young consumers. Young consumers represent a potential market due to their majority population in the demographic profile of several country (Auliandri et al., 2018, Setyawan et al., 2018). In addition to their large numbers in developing countries such as Indonesia, young consumers are also better equipped with m-banking technology. The Indonesian government launched a new people's business credit program as part of a package of economic policy and deregulation (Purwono et al., 2019), and M-banking is expected to be a solution for banking activities of young consumers who are relatively mobile and prioritise convenience and practicality.

Motivated by the research of Akturan and Tezcan (2012), and Sharma and Sharma's study (2019), researchers wanted to examine the role of internal and external factors that influence the intention of using m-banking among young consumers. Internal factors were tested in the form of attitude, perceived usefulness, and trust. Furthermore, service quality and system quality act as external factors.

\section{Literature Review}

In general, m-banking can be defined as one of the m-commerce applications that allows consumers to access banking services through mobile devices, such as smartphones, smart watches, and other smart technology that are mobile (Zhang, Lu, \& Kizildag, 2018). The high mobility of its user to move from one region to another due to their profession (Ushakov \& Auliandri, 2020), or their entrepreneurial effort to setup Business enterprises based on their cultural value to sharpen competitive soft skills (Ambari et al., 2020, Ahdiah et al., 2019), definitely will need the latest technology of m-banking to access financial updates. Akturan and Tezcan (2012) explain the intention to use m-banking in the youth market in the context 
International Journal of Innovation, Creativity and Change. www.ijicc.net

Volume 14, Issue 2, 2020

of perception because the respondents had never used m-banking services before (non-users). The explanatory factors used are the integration of the technology acceptance model (TAM) with perceived benefits and perceived risks. Meanwhile, Sharma and Sharma's research (2019) emphasised the intention to use m-banking on actual users with explanatory variables in the form of trust and quality dimensions.

In this study, researchers attempt to explain the intention to use young consumer m-banking from the perspective of the actual user. The explanatory factors of the intention to use $\mathrm{m}$ banking are divided into internal factors and external factors. Internal factors are factors that represent the internal motivation of consumers to use m-banking: attitude, perceived usefulness, and trust. Internal factors were adapted from the research of Akturan and Tezcan (2012) and Sharma and Sharma (2019). Internal factors are thought to have a positive effect on the intention to use m-banking among young consumers. This means that the higher internal factors perceived by consumers, they will encourage the intention of using m-banking on an ongoing basis. Thus, the research hypothesis related to internal factors is stated as follows.

H1: Attitudes have a positive effect on the intention to use m-banking services among young consumers.

H2: Perceived usefulness has a positive effect on the intention to use m-banking services among young consumers.

H5: Trust has a positive effect on the intention to use m-banking services among young consumers.

The external factors that influence the intention to use m-banking are in the form of supports provided by banks to attract consumers to use m-banking. External factors in this study are represented by the quality dimension adapted from Sharma and Sharma's research (2019). The quality dimensions in this context are service quality and system quality. These quality dimensions are actually the evaluation of actual users of m-banking services. The better quality provided by banks to consumers, the higher the consumers' intention to use m-banking on an ongoing basis. Furthermore, the research hypotheses related to the dimensions of quality as the external factors are written as follows.

H3: Service quality has a positive effect on the intention to use m-banking services among young consumers.

H4: System quality has a positive effect on the intention to use m-banking services among young consumers.

The proposed research model is illustrated in Figure 1 as follows. 
Figure 1. Research Framework

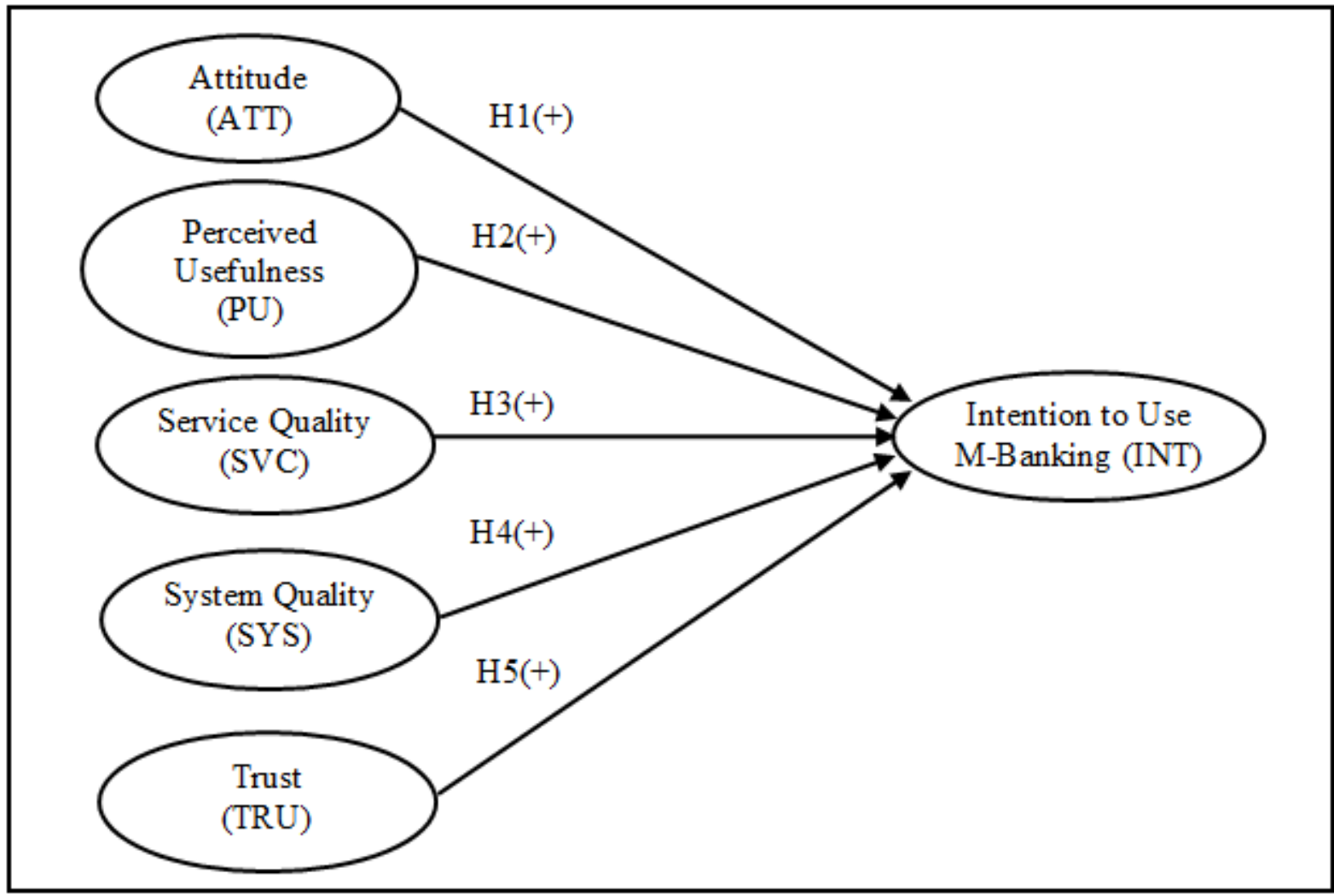

\section{Methods}

The study was conducted using a quantitative confirmatory approach in the philosophy of positivist research (Saunders et al., 2016: 136). The researchers constructed a causal relationship between variables based on theoretical support and the results of previous empirical research to achieve their research objectives (Zikmund et al., 2013: 54). The causal relationships are hypothesised based on the theoretical basis, then tested using empirical data to provide causal explanations and confirmation of the theory used in real phenomena (Cooper \& Schindler, 2011: 141).

Referring to Figure 1, this research seeks to uncover variables that encourage young consumers to use $\mathrm{m}$-banking services. The intention to use m-banking services is called endogenous variables, while the antecedent variables include attitudes, perceived usefulness, service quality, system quality, and trust are referred to as exogenous variables. All research variables were measured using a 5-point Likert scale that was manifested in a scale of 1 (strongly disagree) to 5 (strongly agree). The research variables were operationalised by adapting the research conducted by Akturan and Tezcan (2012), as well as the research of Sharma and Sharma (2019). 
International Journal of Innovation, Creativity and Change. www.ijicc.net Volume 14, Issue 2, 2020

Researchers obtained the data by applying the self-reported survey technique to a number of research respondents. A total of 290 research respondents were selected by purposive sampling technique, namely by selecting respondents based on certain criteria that corresponded to the research objectives (Now \& Bougie, 2016: 248). The criteria of respondents in this study were young consumers of m-banking service users in Indonesia in the age range of 18-30 years. The collected data was then analysed using the structural equation modelling (SEM) technique with 2-stages approach from Anderson and Gerbing (1988), namely the measurement model in the first stage, and followed by the structural model in the second stage.

\section{Results and Discussion}

The SEM analysis in this study was carried out using AMOS 23 software, both in measurement and structural model stages. The results of running AMOS at the measurement model analysis stage showed a fairly good criteria of goodness of fit $(\mathrm{GoF})$ based on the value of $\chi^{2} / \mathrm{df}=$ 2.619; $\mathrm{RMSEA}=0.075 ; \mathrm{GFI}=0.864$; $\mathrm{CFI}=0.936$; and TLI $=0.921$. As GoF already meets the required criteria, the analysis continues on testing the validity and reliability of the data. The results of testing the validity and reliability of the data on the measurement model are shown in Table 1 below.

Table 1. Measurement Model - Validity and Reliability Test

\begin{tabular}{|c|c|c|c|c|c|}
\hline $\begin{array}{l}\text { Items of } \\
\text { Variabl } \\
\text { e }\end{array}$ & $\begin{array}{l}\text { Standardis } \\
\text { ed Factor } \\
\text { Loading } \\
(\lambda)\end{array}$ & $\begin{array}{l}\text { Average } \\
\text { Variance } \\
\text { Extracted } \\
\text { (AVE) }\end{array}$ & $\begin{array}{l}\text { Construct } \\
\text { Reliabilit } \\
\text { y (CR) }\end{array}$ & $\begin{array}{l}\text { Cronbach' } \\
\operatorname{si}\end{array}$ & Remarks \\
\hline \multicolumn{6}{|c|}{ Attitude (ATT) } \\
\hline ATT1 & 0.796 & \multirow{4}{*}{0.644} & \multirow{4}{*}{0.878} & \multirow{4}{*}{0.873} & Valid \& Reliable \\
\hline ATT2 & 0.762 & & & & Valid \& Reliable \\
\hline ATT3 & 0.782 & & & & Valid \& Reliable \\
\hline ATT4 & 0.866 & & & & Valid \& Reliable \\
\hline \multicolumn{6}{|c|}{ Perceived Usefulness (PU) } \\
\hline PU1 & 0.659 & \multirow{4}{*}{0.602} & \multirow{4}{*}{0.856} & \multirow{4}{*}{0.881} & Valid \& Reliable \\
\hline PU2 & 0.682 & & & & Valid \& Reliable \\
\hline PU3 & 0.877 & & & & Valid \& Reliable \\
\hline PU4 & 0.859 & & & & Valid \& Reliable \\
\hline \multicolumn{6}{|c|}{ Service Quality (SVC) } \\
\hline SVC1 & 0.761 & \multirow{3}{*}{0.661} & \multirow{3}{*}{0.853} & \multirow{3}{*}{0.847} & Valid \& Reliable \\
\hline SVC2 & 0.876 & & & & Valid \& Reliable \\
\hline SVC3 & 0.797 & & & & Valid \& Reliable \\
\hline \multicolumn{6}{|c|}{ System Quality (SYS) } \\
\hline SYS1 & 0.795 & 0.630 & 0.836 & 0.833 & Valid \& Reliable \\
\hline
\end{tabular}


International Journal of Innovation, Creativity and Change. www.ijicc.net

Volume 14, Issue 2, 2020

\begin{tabular}{|c|c|c|c|c|c|}
\hline SYS2 & 0.827 & & & & Valid \& Reliable \\
\hline SYS3 & 0.758 & & & & Valid \& Reliable \\
\hline \multicolumn{6}{|c|}{ Trust (TRU) } \\
\hline TRU1 & 0.792 & \multirow{3}{*}{0.664} & \multirow{3}{*}{0.856} & \multirow{3}{*}{0.830} & Valid \& Reliable \\
\hline TRU2 & 0.829 & & & & Valid \& Reliable \\
\hline TRU3 & 0.823 & & & & Valid \& Reliable \\
\hline \multicolumn{6}{|c|}{ Intention to Use M-Banking (INT) } \\
\hline PI1 & 0.794 & \multirow{5}{*}{0.545} & \multirow{5}{*}{0.856} & \multirow{5}{*}{0.862} & Valid \& Reliable \\
\hline PI2 & 0.750 & & & & Valid \& Reliable \\
\hline PI3 & 0.700 & & & & Valid \& Reliable \\
\hline PI4 & 0.757 & & & & Valid \& Reliable \\
\hline PI5 & 0.684 & & & & Valid \& Reliable \\
\hline
\end{tabular}

Referring to Hair et al. (2010: 709-710), the validity of the measurement model is said to be good if it meets the standardised factor loading $(\lambda)$ and minimum AVE value of 0.5 , while the reliability is indicated by a minimum construct value (CR) or Cronbach's alpha $(\alpha)$ of 0.7 . The test results of the measurement model in Table 1 showed the lowest $\lambda$ value of 0.659 , and the lowest value of AVE was 0.545, so all indicators / items of the research variable were declared valid. The lowest $\mathrm{CR}$ value in the measurement model shown in Table 1 was 0.836 , while the lowest value of Cronbach's $\alpha$ was 0.830 , indicating that the reliability criteria were met. Since the validity and reliability of the measurement model have been fulfilled, then a proper analysis is continued to the hypothesis testing stage on the structural model.

The results of the analysis on the structural model are shown in Figure 2 and Table 2 as follow.

Figure 2. The relationship between Research Variables in Structural Models 


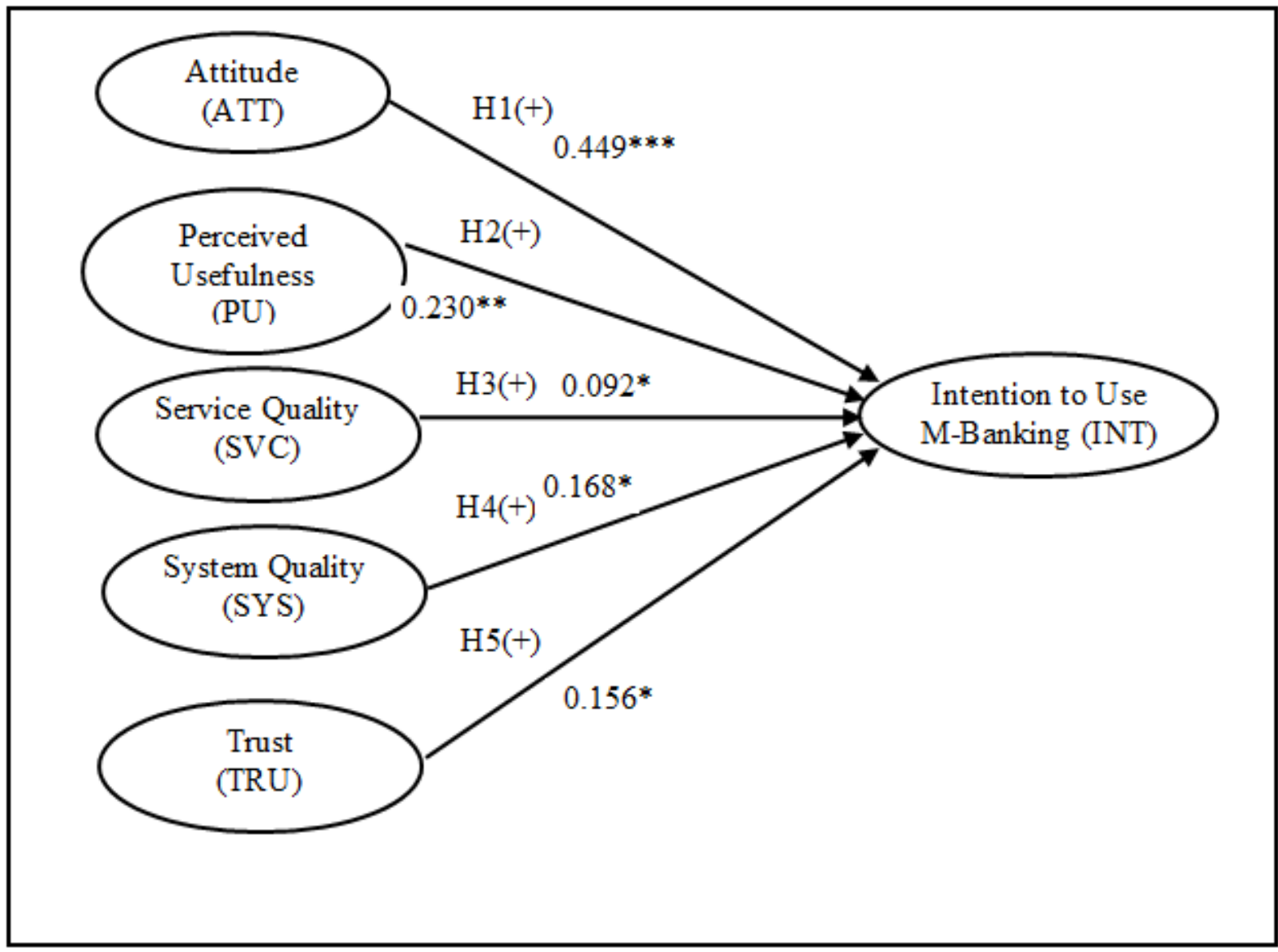

Notes: The values listed are standardised estimate values; $* * * \mathrm{P}$-value $<0.001, * * \mathrm{P}$-value $<0.05, * \mathrm{P}$-value $<0.1$

The structural model in this study has met good GoF criteria based on the values of $\chi^{2} / \mathrm{df}=$ 2.619; $\mathrm{RMSEA}=0.075 ; \mathrm{GFI}=0.864 ; \mathrm{CFI}=0.936$; and $\mathrm{TLI}=0.921$. In the structural model, researchers examined the relationships between variables in a series of hypothesis testing. Figure 2 shows that all exogenous variables have a positive and significant influence on the intention to use m-banking among young consumers. Internal factors which consist of attitude, perceived usefulness, and trust give a positive influence that is greater than external factors. External factors that encourage the intention to use m-banking consist of variable service quality and system quality. A summary of hypothesis testing on the structural model is shown in Table 2.

Table 2: Summary of Hypothesis Testing in Structural Models 
International Journal of Innovation, Creativity and Change. www.ijicc.net Volume 14, Issue 2, 2020

\begin{tabular}{|l|l|l|l|l|l|}
\hline $\begin{array}{l}\text { Hypothe } \\
\text { sis }\end{array}$ & $\begin{array}{l}\text { Path between } \\
\text { Variables }\end{array}$ & $\begin{array}{l}\text { Standardised } \\
\text { Estimates }(\boldsymbol{\beta})\end{array}$ & $\begin{array}{l}\text { Critical } \\
\text { Ratio }(\boldsymbol{C} . \boldsymbol{R} .)\end{array}$ & P-value & Remarks \\
\hline $\mathrm{H} 1(+)$ & ATT $\rightarrow$ INT & 0.449 & 4.208 & $* * *$ & H1 supported \\
\hline H2(+) & PU $\rightarrow$ INT & 0.230 & 2.437 & 0.015 & H2 supported \\
\hline H3(+) & SVC $\rightarrow$ INT & 0.092 & 1.726 & 0.084 & H3 supported \\
\hline H4(+) & SYS $\rightarrow$ INT & 0.168 & 1.747 & 0.081 & H4 supported \\
\hline H5(+) & TRU $\rightarrow$ INT & 0.156 & 1.909 & 0.056 & H5 supported \\
\hline
\end{tabular}

Notes: ***P-value $<0.001, * * \mathrm{P}$-value $<0.05$, $* \mathrm{P}$-value $<0.1$.

Referring to the summary of the hypothesis testing on Table 2 , attitude has the greatest positive influence on the intention to use young consumer m-banking $(\beta=0.449$, P-value $<0.001)$; thus, $\mathrm{H} 1$ is supported. Perceived usefulness shows the second biggest positive effect $(\beta=0.230$, Pvalue $<0.05)$; $\mathrm{H} 2$ is supported. Service quality has a positive and significant effect $(\beta=0.092$, $\mathrm{P}$-value $<0.1$ ); H3 is supported by empirical data. External factors that young consumers think need to be considered in encouraging the intention to use m-banking are system quality $(\beta=$ 0.168 , P-value $<0.1$ ) which supports H4. Among the same external factors, the system quality variable has the greatest positive influence on the intention to use by young consumer $\mathrm{m}$ banking. Finally, the trust variable has a positive effect on the intention to use $\mathrm{m}$-banking $(\beta=$ 0.156 , P-value $<0.1$ ), meaning that H5 is also supported. Hence the entire research hypothesis is supported by empirical data. This means that the intention to use young consumer m-banking services is influenced by attitude, perceived usefulness, service quality, system quality, and trust.

\section{Conclusion}

In the digital era, m-banking is one of the solutions and lifestyles for young consumers to meet the needs of easy, fast, and practical banking services. This study provides an understanding that internal and external factors simultaneously have a positive effect on the intention to use $\mathrm{m}$-banking. The attitudes, perceptions of usability, and trust of the $\mathrm{m}$-banking service providers are internal factors that have a positive and significant effect on the intention to use m-banking services in banking activities for young consumers in Indonesia. Internal factors have a greater positive influence on the intention to use m-banking than external factors. Nevertheless, the influence of external factors also has a positive influence and needs to be considered by service providers to provide maximum service support to young consumers, which in turn encourages the intention to use m-banking on an ongoing basis. Good system quality and service quality are external factors that have a positive influence on the intention to use young consumer mbanking. The better the quality of the system and the quality of the m-banking services offered, the higher the intention of consumers to use m-banking services.

\section{REFERENCES}


International Journal of Innovation, Creativity and Change. www.ijicc.net

Volume 14, Issue 2, 2020

Ahdiah, I., Wirawan, I.B., Suyanto, B., Adam, S., \& Suaedi, F. (2019). Competitiveness of Kaili ethnic human resources in Indonesia. Opcion, 35 (20): 1423-1436

Akturan, U., \& Tezcan, N. (2012). Mobile banking adoption of the youth market: Perceptions and intentions. Marketing Intelligence \& Planning, 30(4): 444 - 459.

Alalwan, A. A., Dwivedi, Y. K., \& Rana, N. P. (2017). Factors influencing adoption of mobile banking by Jordanian bank customers: Extending UTAUT2 with trust. International Journal of Information Management, 37(3): 99 - 110.

Ambari, R.D., Permana, I.B.G.A., \& Arina, N.A. (2020). Mediating role of entrepreneurial attitudes in the relationship between adversity quotient, self-efficacy, and entreprenurial intention. International Journal of Psychosocial Rehabilitation, 24(7): 885-889.

Anderson, J. C., \& Gerbing, D. W. (1988). Structural equation modeling in practice: A review and recommended two-step approach. Psychological Bulletin, 103(3): 411 - 423.

Auliandri. T. A., Armanu, A., Rohman, F., \& Rofiq, A. (2018). Does green packaging matter as a business strategy? Exploring young consumers' consumption in an emerging market. Problems and Perspectives in Management, 16 (2): 376-384.

Baabdullah, A. M., Alalwan, A. A., Rana, N. P., \& Kizgin, H. (2019). Consumer use of mobile banking (M-Banking) in Saudi Arabia: Towards an integrated model. International Journal of Information Management, 44: 38 - 52.

Cooper, D. R., \& Schindler, P. S. 2011. Business research methods (11th ed.). New York, NY: McGraw-Hill.

Hair Jr, J. F., Black, W. C., Babin, B. J., \& Anderson, R. E. (2010). Multivariate data analysis (7th ed.). Englewood Cliffs, NJ: Prentice-Hall.

Purwono, R., Nugroho, R.Y.Y., \& Mubin, M.K. (2007). Response on new credit program in Indonesia: An asymmetric information perspective. Journal of Asian Finance, Economics and Business, 6 (2) : 33-44

Saunders, M., Lewis, P., \& Thornhill, A. (2016). Research methods for business students (7th ed.). Pearson Education Ltd.

Sekaran, U., \& Bougie, R. (2016). Research methods for business: A skill building approach (7th ed.). John Wiley \& Sons Ltd. 
International Journal of Innovation, Creativity and Change. www.ijicc.net Volume 14, Issue 2, 2020

Setyawan, A., Noermijati, N., Sunaryo, S., \& Aisjah, S. (2018). Green product buying intentions among young consumers: Extending the application of theory of planned behavior. Problems and Perspectives in Management, 16 (2): 145-154.

Shareef, M. A., Baabdullah, A., Dutta, S., Kumar, V., \& Dwivedi, Y. K. (2018). Consumer adoption of mobile banking services: An empirical examination of factors according to adoption stages. Journal of Retailing and Consumer Services, 43: 54 - 67.

Sharma, S. K., \& Sharma, M. (2019). Examining the role of trust and quality dimensions in the actual usage of mobile banking services: An empirical investigation. International Journal of Information Management, 44: 65 - 75.

Ushakov, D., \& Auliandri, T.A. (2020). International Labor Migration in South Asia: Current Situation and the Problems of Efficient National Regulation. IOP Conference Series: Materials Science and Engineering, 753(8), 101-108.

Zhang, T., Lu, C., \& Kizildag, M. (2018). Banking “on-the-go": Examining consumers' adoption of mobile banking services. International Journal of Quality and Service Sciences, 10: $279-295$.

Zhang, Y., Weng, Q., \& Zhu, N. 2018. The relationships between electronic banking adoption and its antecedents: A meta-analytic study of the role of national culture. International Journal of Information Management, 40: 76 - 87.

Zikmund, W. G., Babin, B. J., Carr, J. C., \& Griffin, M. (2013). Business research methods (9th ed.). New York, NY: McGraw-Hill. 